\title{
Effect of chemical and thermochemical treatments on the surface properties of commercially pure titanium
}

\author{
Alejandro López Cruz ${ }^{1,4}$, Adrian Paz Ramos ${ }^{2}$ \\ Leonardo M. Pazos ${ }^{3}$, María Belén Parodi ${ }^{3}$ \\ Gabriel Omar Ybarra ${ }^{3}$, Jesús E. González Ruíz ${ }^{4}$
}

\footnotetext{
${ }^{1}$ Department of Mechanical and Electric Engineering, Autonomous University of Nuevo León, Mexico.

${ }^{2}$ Department of Chemistry, Université de Montréal, Succursale Centre-Ville, QC, Canada.

${ }^{3}$ National Institute of Industrial Technology, San Martin, Buenos Aires, Argentina.

${ }^{4}$ Department of Ceramic and Metallic Biomaterials, Biomaterials Center, University of Havana, Havana, Cuba. e-mail: alejandrolcr91@gmail.com, a.paz.ramos@umontreal.ca, lpazos@inti.gob.ar, belen@inti.gob.ar, gabriel@inti.gob.ar, jesus.gonzalez@biomat.uh.cu,mparodi@inti.gob.ar
}

\begin{abstract}
Chemical and physical methods have been generally used for modifying the surface of titanium implants with the aim of achieving better osseointegration. In this work, an evaluation of the effect of different chemicals and thermochemical treatments on the surface modification of titanium was carried out. Plates of commercially pure titanium were polished and treated with four different methods. Scanning electron microscopy, atomic force microscopy, energy-dispersive X-ray spectroscopy, infrared spectroscopy, X-ray diffraction and drop shape analysis were used to characterize the modified titanium surface. Our results showed that the AEPTTT surface exhibited the highest Ra values followed by AEAT, AEPT, polished Ti and AE samples. In addition, the AEAT and AEPTTT treatments developed the largest surface area, while the AE treatment produced the lowest surface area. Furthermore, the AEAT treatment created the most hydrophilic surface, which is known to positively affect the osseointegration rate of dental implants.
\end{abstract}

Keywords: Titanium, surface modification, hydrogen peroxide treatment, alkali treatment, thermochemical treatment.

\section{INTRODUCTION}

The osseointegration of titanium implants and its alloys requires long implantation times [1]. Several works report the formation of fibrous tissue on the surface of titanium implants, a fact that negatively influences its behavior in vivo [2,3]. The modification of the chemistry and phase compositions of the surface has been tested with success to improve both the biocompatibility and bioactivity of the titanium [4, 5]. In order to achieve this purpose, coatings of calcium phosphates, oxides, hydroxides, and titanates have been used [6-9]. Also, the modification of the surface roughness and (or) topography has been successfully employed to enhance bioactivity on titanium and its alloys [7, 10]. It is known that surface roughness influences the adhesion, growth, and cell proliferation processes [11, 12]. Additionally, the combination of the chemical (or phase) composition and surface roughness also has an influence on the bioactivity of titanium implants [13]. The surface contact angle (wettability) is another key factor that influences this parameter [14].

In the past years, several new surface treatments have been reported to achieve these purposes [15-17]. These treatments are based on physical or chemical principles [18]. For example, in order to modify the surface roughness and topography of titanium, different treatments have been used, such as blasting, acid etching, electrochemical and thermochemical treatments, plasma spray and its combinations [6, 19-21]. The combination of acid etching with a treatment in hydrogen peroxide - hydrochloric acid mixture and further thermochemical treatments has increased the bioactivity of titanium and reduced the osseointegration time of dental implants $[4,7,8,19,22]$. Also, the incorporation of calcium, sodium or phosphate ions to the titanium surface has been investigated with promising results [7, 22-24]. A successful application of a porous coating doped with phosphate ions on dental implants was reported by SUL et al. [25]. In addition, alkaline treatments based on sodium incorporation to the titanium surface with the purpose of enhancing the bioactivity of the modified surface have been reported [26]. 
Other research has been focused on increasing the wettability of the titanium surface. A treatment called Sandblasted and acid-etched (SLActive ${ }^{\circledR}$ ) and developed by the Institute Straumann showed an increase in the performance of dental implants in vivo [27]. Additionally, according to ELIAS et al. [28], the titanium dental implants subjected to different surface treatments show a high value of reversible torque when its surface was more hydrophilic and when had a high superficial roughness. The wettability of titanium is also related to the chemical composition of its surface [18]. RUPP et al. found that high values of the surface roughness $(\mathrm{Ra})$ increased the hydrophilic of the titanium surface [29]. The titanium implants with superhydrophilic and micro-rough surfaces have attracted much interest due to their osseointegration potential. Super-hydrophilic implants have shown an increase in the bone-implant contact area and a strong mechanical fixation in the early healing phase [29, 30].

Different parameters of surface roughness (average height, peak distance, number of peaks) and topography have an influence on the surface area of the titanium implants [28]. However, the effect of surface area on the wettability of titanium has not been sufficiently studied. In addition, the study of the combined effect of the variables: surface roughness, topography, elemental and phases composition in titanium surfaces can be a suitable alternative for obtaining superior properties at the bone-implant interface in order to decrease the osseointegration time of implants.

The present paper aims to compare the topography, surface roughness, surface area and contact angle (wettability) obtained using the most common surface treatments applied to commercially pure titanium. Also, we introduced some modifications to these methods in order to improve the published results. We developed a simple chemical treatment using a combination of acid etching and alkali treatment in order to obtain a hierarchical micro/nano-structured surface on commercially pure titanium.

\section{MATERIALS AND METHODS}

Commercially pure titanium plates $(20 \times 5 \times 1 \mathrm{~mm})$, grade 2 , were polished using silicon carbide emery paper from 120 to 600 mesh. Then, the samples were cleaned with abundant distilled water and dried in a stove at $60{ }^{\circ} \mathrm{C}$ for $1 \mathrm{~h}$. All samples were immersed in a mixture of 2.75M HF / 3.94M HNO3 v/v 1:1 for two minutes at room temperature (acid etching, AE variant). Afterward, the samples were extracted from the acid mixture and rinsed with abundant distilled water. Then, they were placed in an ultrasonic bath with distilled water for 15 minutes and finally dried in a stove at $60{ }^{\circ} \mathrm{C}$ for $1 \mathrm{~h}$. In the second surface treatment (AEPT), after acid etching, the samples were immersed in a mixture of $8.8 \mathrm{M} \mathrm{H}_{2} \mathrm{O}_{2} / 0.1 \mathrm{M} \mathrm{HCl} \mathrm{v/v} 1: 1$ at $80{ }^{\circ} \mathrm{C}$ for 30 minutes. Then, the samples were rinsed with distilled water and dried in a stove at $60^{\circ} \mathrm{C}$ for $1 \mathrm{~h}$. Additionally, some AEPT samples were subjected to further thermochemical treatment in air at atmospheric pressure, at $400^{\circ} \mathrm{C}$ for $1 \mathrm{~h}$ (AEPTTT variant). In the fourth variant (AEAT), some AE samples were immersed in a $10 \mathrm{M} \mathrm{NaOH}$ aqueous solution at $60{ }^{\circ} \mathrm{C}$ for $24 \mathrm{~h}$. After the treatment process, the samples were removed from the solution, rinsed with abundant distilled water, and dried in a stove at $60{ }^{\circ} \mathrm{C}$ for $1 \mathrm{~h}$.

Infrared spectroscopy (IR) was used for the identification of functional groups. The spectra were collected in the 400-4000 $\mathrm{cm}^{-1}$ wavenumber range using a Nicolet Magna 550 Series II Fourier Transform infrared spectrometer with a diffuse reflectance accessory (SpectraTech). The modified surfaces were also investigated by X-ray diffraction (XRD) using a Thermo Electron XTRA diffractometer with a CuK $\alpha$ radiation $(\lambda=1.54056$ $\AA$ ) in the range of $2 \theta=20-50^{\circ}$ with a resolution of $0.01^{\circ}$. The PCPDFWIN database, v. 2.4 ICDD PDF$2 / 2003$ was used for the identification of the chemical phases.

The micrographs of the surfaces were obtained using a scanning electron microscope Philips 505, while the chemical composition was determined by energy-dispersive X-ray spectroscopy. The topography and surface roughness of the samples were acquired using an atomic force microscope (Surface Imaging Systems). All measurements were performed in non-contact mode over an area of $36 \times 36 \mu \mathrm{m}$. The arithmetic average of the absolute height values of the profile $(\mathrm{Ra})$, the maximum peak-to-valley height $(\mathrm{Rmax})$ and the surface area $(\mathrm{S})$ were obtained using the SIScanPro v1.3 software.

The measurements of the contact angle formed between the treated surfaces and drops of a solution with a high content of calcium and phosphate ions (SCS) was performed using an optical contact angle measuring system Dataphysics OCA 10. Five samples were employed for each surface, using drops of $15 \mu \mathrm{L}$. The composition of the SCS solution was previously reported [31]. The contact angle reported was the average value of a total of 10 measurements. The measurements were performed at room temperature, with controlled relative humidity.

The roughness parameters ( $\mathrm{Ra}$ and Rmax), the surface area and the contact angle of the four treated surfaces were compared using Statgraphics Centurion XV software. The differences between these parameters were evaluated using a multiple range comparison with multiple range tests. A confidence level of $95 \%(\mathrm{p}<0.05)$ was considered statistically significant. 


\section{RESULTS AND DISCUSSION}

\subsection{Characterization of the polished surface}

The polished titanium surface (Figure 1A) showed several scratches aligned in the direction in which the abrasive particles were displaced during the polishing process. This result was confirmed in the micrographs from atomic force microscopy (AFM) (Figure 1B and C). AFM characterization of this sample showed a surface area of $1447 \mu \mathrm{m}^{2}$ and an average value of surface roughness (Ra) of $1060 \pm 232 \mathrm{~nm}$.
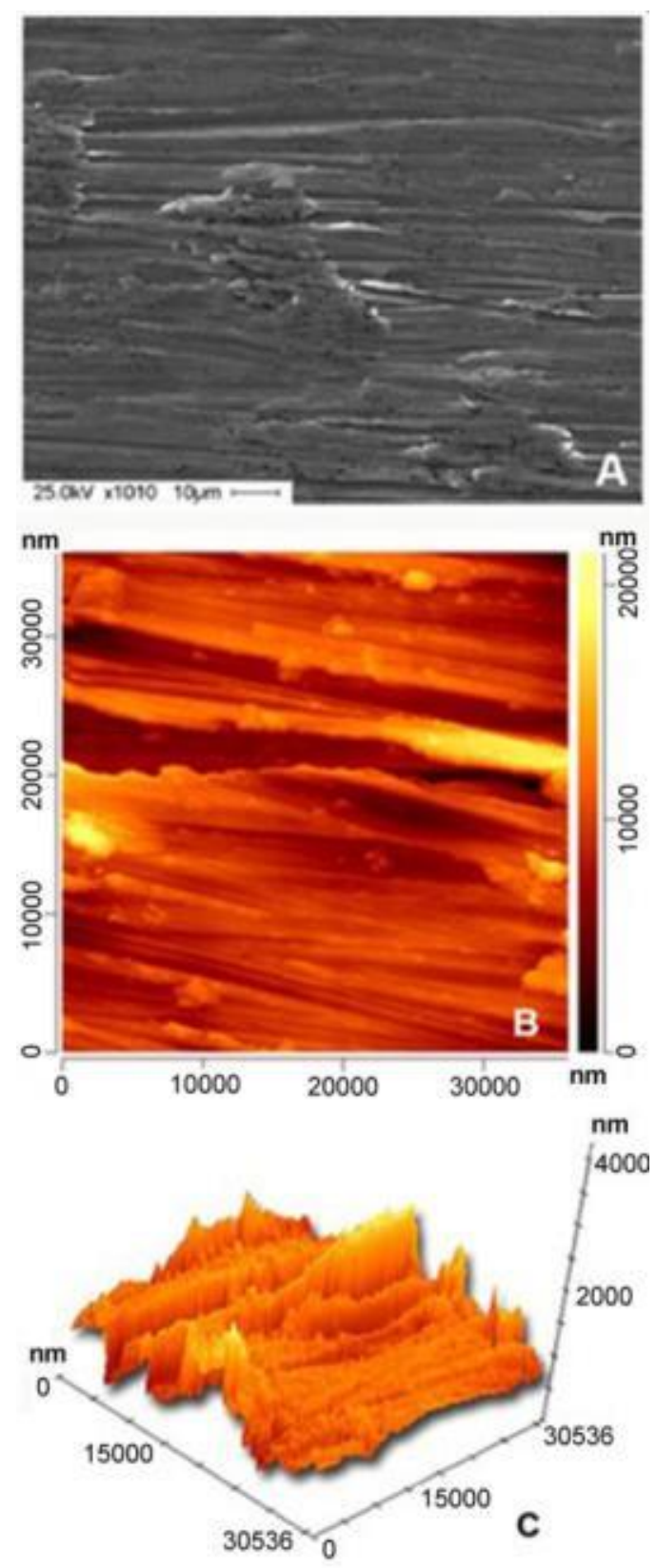

Figure 1: SEM (A) and AFM (B and C) micrographs of the polished titanium surface.

EDS analysis of the elemental composition of the polished surface of titanium showed two main peaks corresponding to titanium, without any further signals from other elements (Figure 2A). It is important to show that there are no contaminants, regarding the treatment performed. This observation was corroborated by XRD analysis (Figure 2B). 


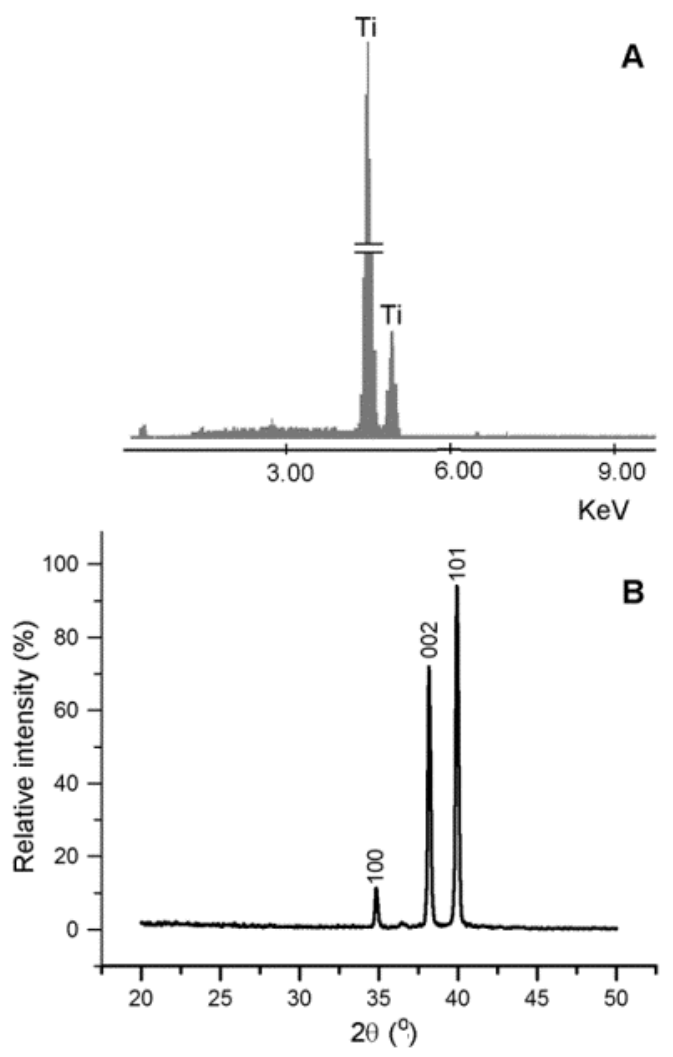

Figure 2: EDS spectrum (A) and X-ray diffraction patterns (B) of the polished titanium surface.

\subsection{Characterization of the modified surfaces}

The morphology and topography of the treated surfaces showed significant differences between them. AE treatment cleaned the surface from native oxides and other impurities. This sample showed the absence of scratches observed after the polishing process (Figure 3A), which were replaced by cavities on the surfaces with dimensions between 3 and $15 \mu \mathrm{m}$. Also, it was observed the formation of micro-cavities of about $1 \mu \mathrm{m}$ inside the cavity walls.

The subsequently AEPT treatment did not significantly change the shape of the cavities formed during the AE treatment. However, this second treatment caused the formation of numerous micro- and submicron cavities throughout the entire surface and inside the aforementioned AE cavities (Figure 3B). It was also impossible to observe the micro-cavities generated during the acid etching. The micro-cavities found in the samples under the AEPT treatment were not observed in the AEPTTT surfaces (Figure 3C), and at low magnification, only cavities similar to those formed on AE surfaces were observed.

The AEAT treatment showed a hierarchical micro/nano-structured surface. In this sample, the cavities formed during the acid etching were observed at low-magnification SEM (Figure 3A). However, their edges were less sharp than those on the AE surface. These cavities had a size between 5 and $18 \mu \mathrm{m}$. In addition, high-magnification SEM images showed a porous network structure (Figure 3E and F). This surface was entirely covered by submicron or nano-cavities (with a size between 48 and $540 \mathrm{~nm}$ ), separated by thin walls (with a thickness between 12 and $76 \mathrm{~nm}$ ). Furthermore, some isolated structures with globular shape and size under $3 \mu \mathrm{m}$ were observed.

The AEAT surfaces also showed some micro-cracks (Figure 3D, E, and F), which could affect the mechanical properties of the coating, with the resulting decrease in the performance of the biomedical device. However, similar cracks were found in previous studies when using the alkali-treatment on titanium and its alloys, with no impact on their mechanical behavior [32]. 


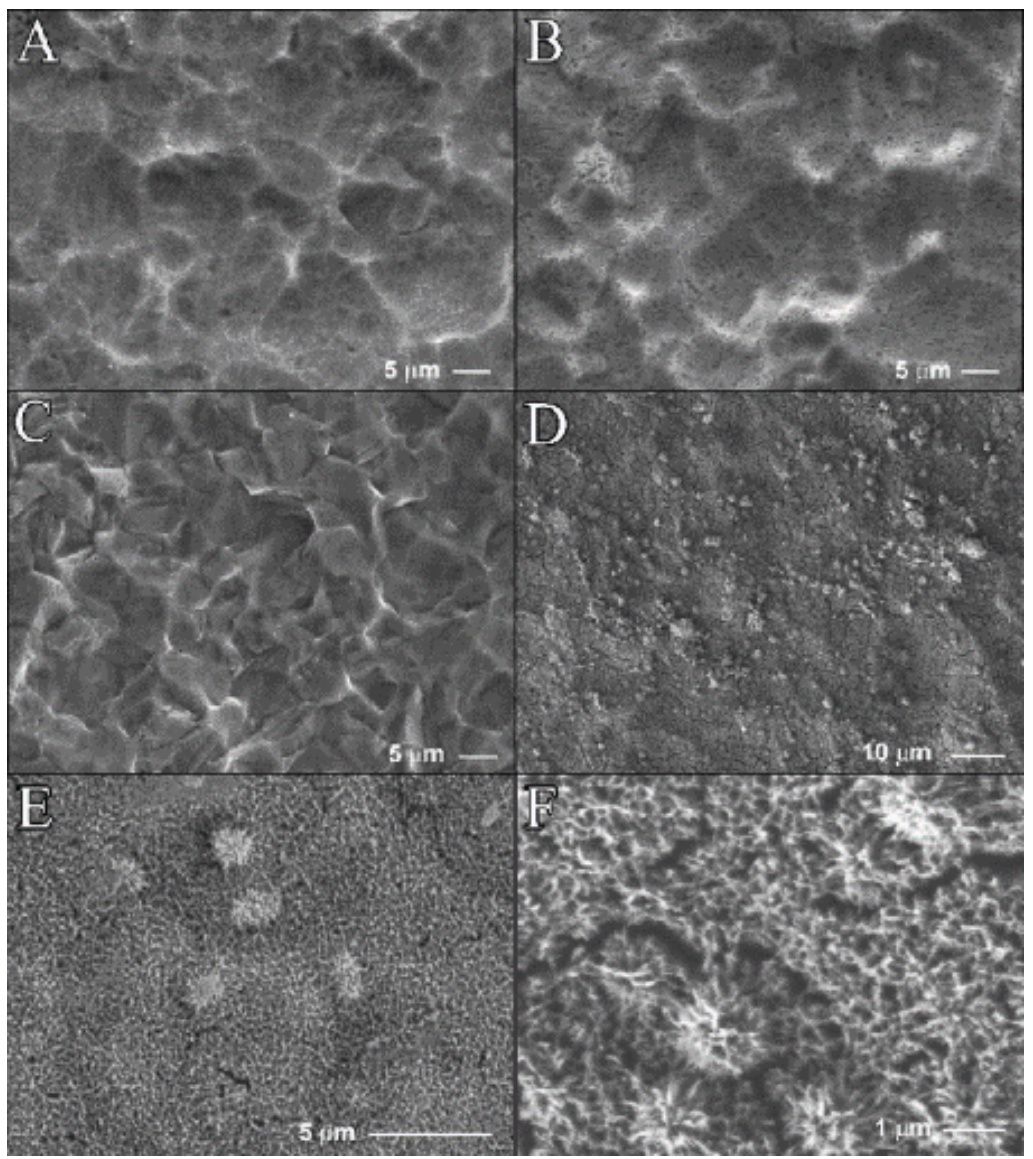

Figure 3: SEM images of the titanium surface modified by four different treatments: A) AE, B) AEPT, C) AEPTTT, DF) AEAT.

In general, AFM images (Figure 4A, B, C, and D) of the four studied surfaces corroborate the morphologies and topographies previously observed by SEM.

AFM images showed the changes in morphology and topography of AE surface in comparison with the polished surface (Figure 4A). In addition, it was determined that the cavities formed on the titanium surface during the AE treatment had a depth greater than $2 \mu \mathrm{m}$. In the AEAT surface, it was observed more peaks and valleys formed during the treatment than in the rest of the surfaces. Also, it was corroborated the multiscale topography in this surface, which was formed by micro-submicron-nano cavities (Figure 4D). In addition, the submicron and nano-cavities were distributed all over the surface, showing a depth of about $1 \mu \mathrm{m}$ (Figures 3D and4D) and a perpendicular orientation to the surface. 

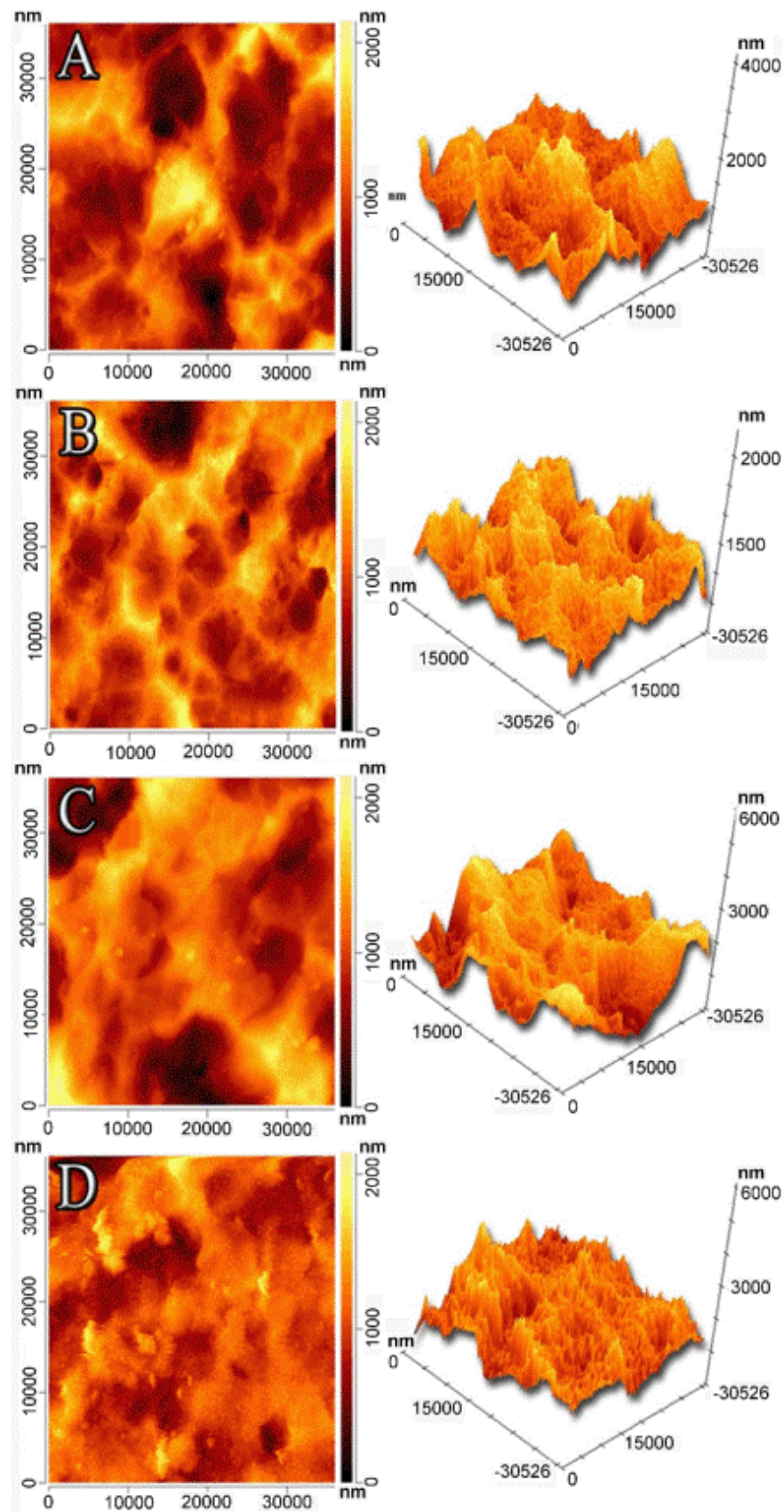

Figure 4: AFM images (two-dimensional and three-dimensional) of the titanium surface with different surface treatments: A) - AE, B) - AEPT, C) - AEPTTT and D) - AEAT.

The AEPTTT surface (Figures 3C and 4C) showed the highest values of Ra and Rmax (Figure 5), which could be associated with the increase of the oxide layer thickness during the thermochemical treatment. The largest surface area was obtained using the AEAT; however, its surface roughness (Ra and Rmax) was lower than those obtained in the surface AEPTT. This behavior should be related to its hierarchical surface. The surface roughness values (Ra and Rmax) and surface area (Figure 5) obtained in the AE and AEPT surfaces showed no statistically significant differences between them. 


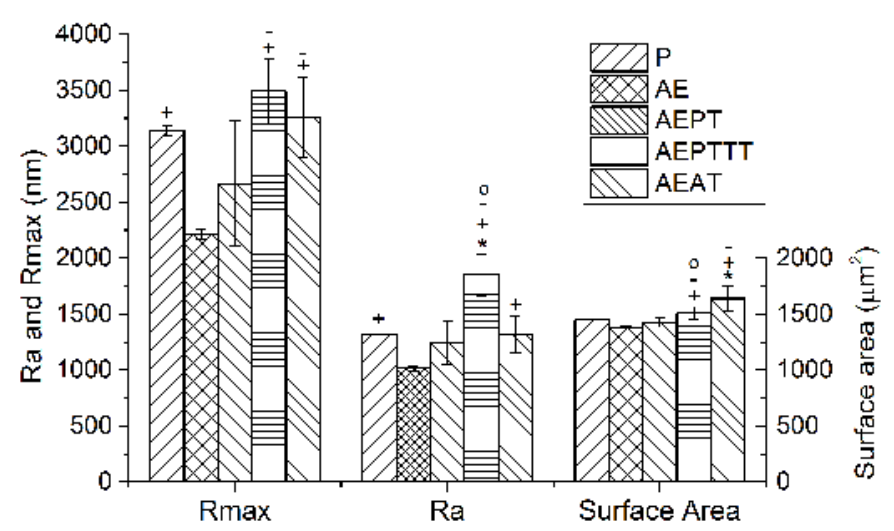

Figure 5: Influence of surface modification treatments on the surface roughness and surface area. Statistically significant differences with: + AE surface, * polished surface (P), - AEPT surface and o AEAT surface.

Surface roughness values (Ra and Rmax) of the AEPTTT and AEAT samples showed statistically significant differences with AE surface (Figure 5). Also, Ra value obtained in the AEPTTT surface showed a statistically significant difference with rest of surfaces. Furthermore, the surface area of the AEAT and AEPTTT surfaces showed statistically significant differences with the rest of surfaces.

In general, the four surface modifications used in this work produced micro-roughness surfaces (Ra) on the titanium, in levels between $1.0 \mu \mathrm{m}$ and $1.8 \mu \mathrm{m}$. Several experimental results have demonstrated that the rate of osseointegration and the biomechanical fixation of titanium implants are influenced by its surface roughness [33-35]. It was found that a moderately rough surface exhibited a better bone response than a smooth or rough surface [36, 37]. WENEBERG et al. [36] advised that a titanium surface roughness (Sa) between 1 and $2 \mu \mathrm{m}$ should have a strong bone response. This behavior is probably related to the biological responses on the cellular level, which are directly influenced by the surface topography. Osteoblast proliferation and its differentiation on the titanium surface, as well as the production of local growth factors and cytokines, are affected by the surface roughness and topography [38]. In addition, the surface roughness is a key factor on the titanium surface wettability. Roughness and wettability both interfere with protein adsorption processes during host tissue - implant contact [22,39].

The IR spectrum of the AE surface does not show any band (Figure 6A). This result proved the effectiveness of the treatment in the removal of oxides and other impurities on polished surfaces. The AEPT treatment changed the chemical composition of the AE surfaces due to the formation of titanium peroxo complexes (Figure 6B). This was assumed by the appearance of two bands in the infrared spectrum located at $570 \mathrm{~cm}-1$ and $1000 \mathrm{~cm}-1$, which corresponds to $\mathrm{O}-\mathrm{O}$ and Ti-O vibrations of the peroxide group on the titanium surface [40]. It has been shown that the formation of bone-like apatite on titania gels is induced by the Ti-O-groups present on its surface. According to ZHANG et al. [8], a large number of Ti-O- groups are necessary for inducing the apatite nucleation in titanium surfaces.

The subsequent application of a thermochemical treatment modified the AEPT surfaces. As a result, the peroxide groups were transformed into oxide (Figure 6C), presumably forming titanium dioxide in the anatase variety. The presence of a strong band at about $800 \mathrm{~cm}-1$ corresponding to the Ti-O vibration in anatase and the disappearance of the peroxide group bands, corroborates this result [41]. The IR spectrum of the AEAT surface showed a strong band located at $650 \mathrm{~cm}-1$ and another strong and broad band near to $880 \mathrm{~cm}-1$, which were previously reported to the Ti-O vibrations in the titanate group (TiO32-) and rutile, respectively (Figure 6D) [42, 43]. It also showed a band at about $1640 \mathrm{~cm}-1$ belonging to the $\mathrm{H}-\mathrm{O}-\mathrm{H}$ vibration caused by the adsorption of water, and finally a broad band located at $3400 \mathrm{~cm}-1$ which was also associated with $\mathrm{O}-\mathrm{H}$ vibration of adsorbed water. In this surface, a mixture of one or more compounds of the sodium titanates family and titanium dioxide could be obtained, presumably from the rutile variety. Besides, the high intensity of the bands corresponding to the water absorption could be indicative of the high wettability values showed on the AEAT surface. 


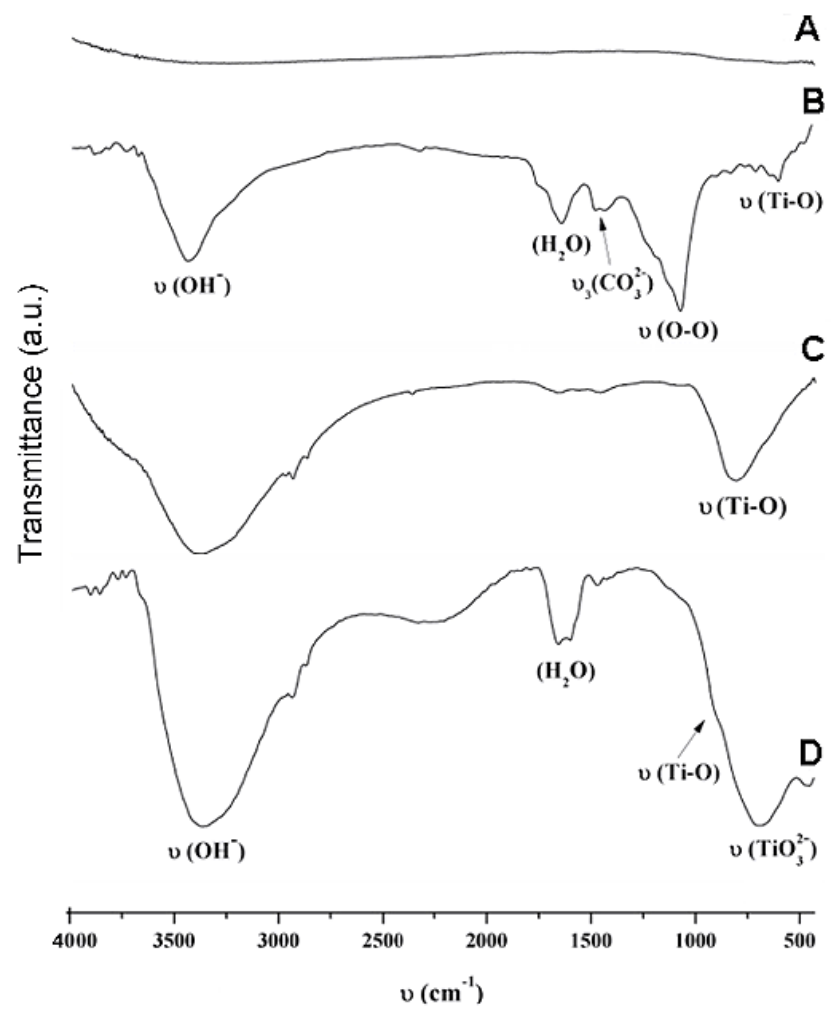

Figure 6: IR spectra of the titanium samples under different surface modification treatments: A) AE, B) AEPT, C) AEPTTT, and D) AEAT.

The XRD patterns of the treated surfaces using the AE and AEPT variants showed only the characteristic peaks of titanium (Figure 7A and B). The absence of peaks corresponding to the titanium oxide in the treated samples using the AEPT variant (Figure 7B), did not match with the results obtained by IR. This result must be related to the amorphous nature of the products formed during the reaction of titanium with peroxide and the nanometric thickness of the layer [44].

During the thermochemical treatment, the amorphous structure of the AEAT surface was transformed into crystalline titanium dioxide (anatase variety) [45-47]. In the diffraction patterns of the AEPTTT surface (Figure 7C), two peaks of low intensity were observed on $25.1^{\circ}$ and $36.5^{\circ}$, corresponding to reflection 101 and 004 of the anatase. The intensity of these peaks was related to the low thickness of the oxide layer, which has been reported between 30 and $200 \mathrm{~nm}[48,49]$.

The X-ray diffraction patterns of AEAT sample (Figure 7D) showed a mixture of rutile and sodium pentatitanate $\left(\mathrm{Na}_{2} \mathrm{Ti}_{5} \mathrm{O}_{11}\right)$. The peaks observed in $2 \theta=27.8^{\circ}, 35.4^{\circ}, 41.5^{\circ}$ to $36.4^{\circ}$ were assigned to rutile, while that the peaks in $2 \theta=12.2^{\circ}, 24.8^{\circ}, 30.6^{\circ}, 44.5^{\circ}$, and $48.7^{\circ}$ were assigned to the sodium pentatitanate. The low relative intensity of the peaks corresponding to both phases denotes a low layer thickness and (or) low-crystalline structures. 

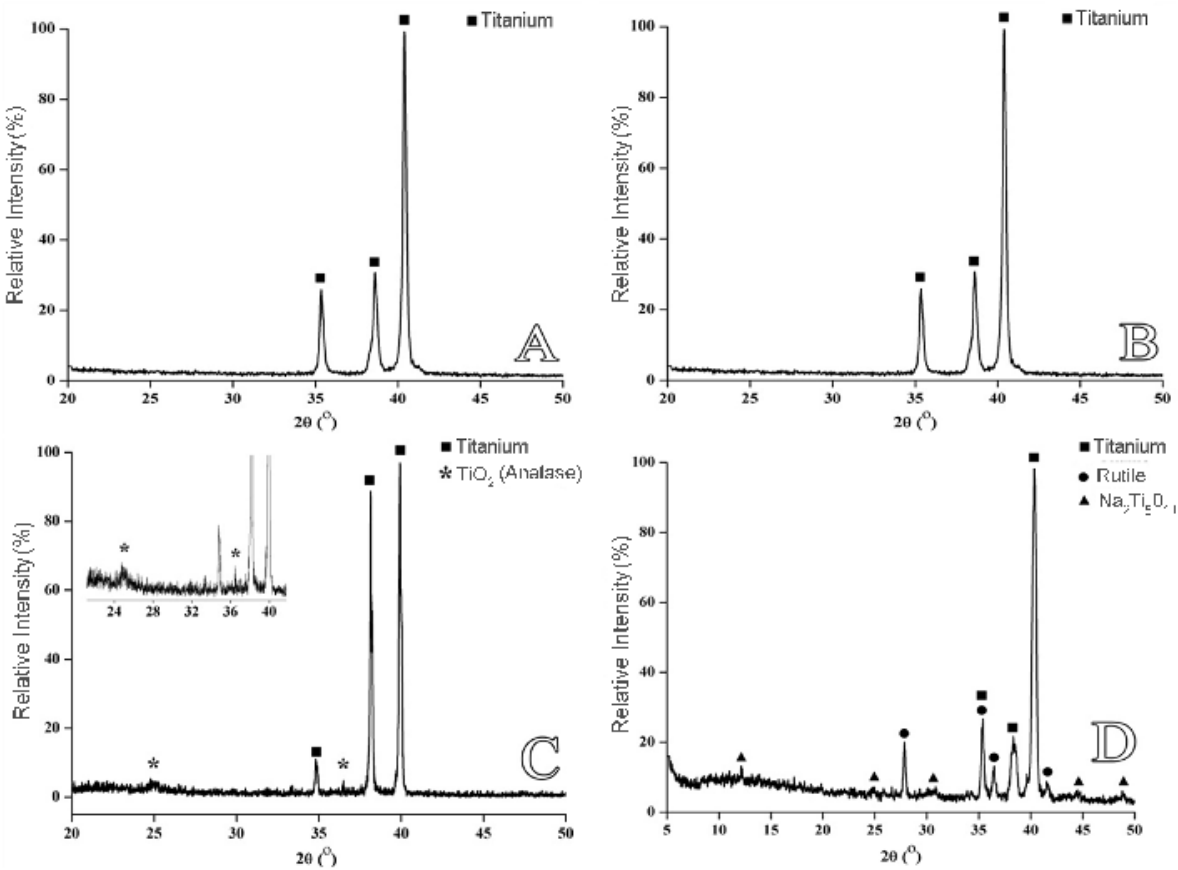

Figure 7: X-ray diffraction patterns of titanium samples under different surface modification treatments: A)- AE, B) AEPT, C) - AEPTTT and D) -AEAT.

Figure 8 showed the contact angle values of all surfaces under different surface modification treatments. The contact angle of the AEAT surface exhibited the lowest value of all samples, showing statistically significant differences with the rest of the surfaces under study. Also, statistically significant differences between the contact angles of the surfaces AEPTTT and AE were found.

On the other hand, no statistically significant differences were found between the contact angles of the other surfaces. The contact angle of all the studied surfaces was lower than $90^{\circ}$ (Figure 8), indicating their hydrophilic nature. Additionally, an increase in the wettability was observed with the increase of the surface area, showing that the AEAT surface was the most hydrophilic surface. Here, it is important to consider the effect of the surface chemistry, since the formation of hydrated $\mathrm{Na}_{2} \mathrm{Ti}_{5} \mathrm{O}_{11}$ on the AEAT surface could be responsible for the higher wettability of this surface, compared with the rest of the phases obtained in this work [50].

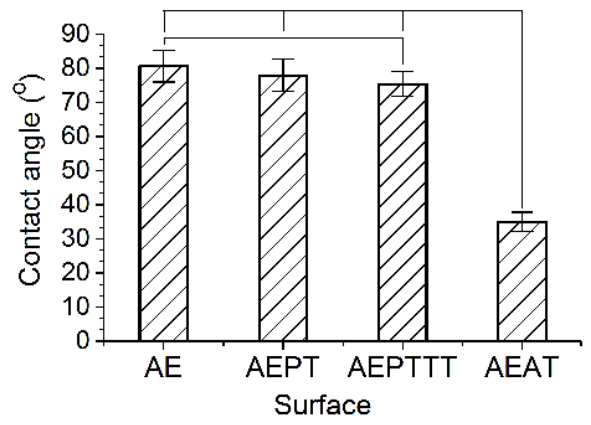

Figure 8: Contact angle of the modified surfaces.

The influence of the surface wettability on the interactions between the implant surface and the surrounding biological environment is already known [51-53]. The hydrated $\mathrm{TiO}_{2}$ at the implant surface interacts with inorganic ions (calcium and phosphate) and organic molecules (proteins, lipoproteins, and peptides) from the biological environment [51]. This interaction allows the formation of a bone-like apatite layer on the surface, increasing the implant osseointegration rate.

In this work, the AEPTTT and AEAT surfaces with micro and nanostructured topography showed the highest contact angle compared with the rest of the surfaces. ZHANG et al. [19] have found an increase of the wettability of the samples with sandblasting with large-grit corundum and acid-etched (SLA) treatments plus SLA 
surface with alkali treatment or $\mathrm{H}_{2} \mathrm{O}_{2} / \mathrm{HCl}$ treatment. They reported a higher cell attachment, proliferation ratio, ALP activity and calcium deposition quantity than SLA and Ti-control surfaces for MC3T3-E1 cells. Also, they have found good osseointegration of both surfaces with host bone in animal studies.

\section{CONCLUSIONS}

The treatments used in this work modified the topography, morphology and surface roughness of the polished surface of commercially pure titanium. The resulting surfaces showed surface roughness (Ra) values between $1.0 \mu \mathrm{m}$ and $1.8 \mu \mathrm{m}$. Also, the values of contact angle were lower than $90^{\circ}$, indicating their hydrophilic nature. These results should favor the osseointegration processes on the four surfaces under study. In addition, AEPTTT and AEAT surfaces showed changes in its chemical and phase composition in comparison with the polished titanium surface. The formation of hydroxyl groups and $\mathrm{TiO}_{2}$ were observed in both surfaces (anatase on AEPTTT surface and rutile on AEAT surface). Also, it was detected the presence of amorphous sodium pentatitanate $\left(\mathrm{Na}_{2} \mathrm{Ti}_{5} \mathrm{O}_{11}\right)$ on the AEAT surface. These phases should modify the contact angle of both surfaces by increasing their wettability.

In the most promising surface (AEAT), a multiscale topography (formed by micro- submicron- and nanopores) was obtained using a simple chemical method, with no drawbacks such as thermal treatment at high temperatures. This surface showed the largest surface area, although its surface roughness values (Ra and Rmax) were lower than those presented by the APTT surface. This result should be related to its hierarchical micro/nano-structured surface. In addition, the AEAT surface showed the highest wettability values, which is linked to its multiscale topography and phase composition.

\section{BIBLIOGRAPHY}

[1] KHAN, S.N., RAMACHANDRAN, M., KUMAR, S.S., et al, "Osseointegration and more: A review of literature", Indian Journal of Dentistry, v. 3, pp. 72-76, 2012.

[2] PLECKO, M., SIEVERT, C., ANDERMATT, D., et al, "Osseointegration and biocompatibility of different metal implants-a comparative experimental investigation in sheep", BMC musculoskeletal disorders, v. 13, pp. 32, 2012.

[3] WILLIE, B.M., YANG, X., KELLY, N.H., et al, "Cancellous bone osseointegration is enhanced by in vivo loading", Tissue Engineering Part C: Methods, v. 16, pp. 1399-1406, 2010.

[4] BAUER, S., SCHMUKI, P., MARK, K.v.d., et al, "Engineering biocompatible implant surfaces Part I: Materials and surfaces", Progress in Materials Science, v. 58, pp. 261-326, 2013.

[5] VARIOLA, F., VETRONE, F., RICHERT, L., et al, "Improving biocompatibility of implantable metals by nanoscale modification of surfaces: an overview of strategies, fabrication methods, and challenges", small, v. 5, pp. 996-1006, 2009.

[6] CHRCANOVIC, B.R., MARTINS, M.D., "Study of the Influence of Acid Etching Treatments on the Superficial Characteristics of Ti", Materials Research, v. 17, pp. 373-380, 2014.

[7] KOKUBO, T., YAMAGUCHI, S., "Bioactive Titanate Layers Formed on Titanium and Its Alloys by Simple Chemical and Heat Treatments", The Open Biomedical Engineering Journal, v. 9, pp. 29-41, 2015.

[8] ZHANG, F., ZHANG, C.-F., YIN, M.-n., et al, "Effect of heat treatment on H2O2/HCl etched pure titanium dental implant: An in vitro study", Med Sci Monit, v. 18, pp. BR265-272, 2012.

[9] AVÉS, E.P., SADER, M.S., JERÔNIMO, F.A.R., et al. "Comparative Study of Hydroxyapatite Coatings Obtained by Sol-Gel and Electrophoresis on Titanium Sheets", Revista Matéria, v. 12, pp. 156-163, 2007.

[10] GRINSCHPUN, L.O., SCHNEITER, M., "Obtención de compuesto de titanio con gradiente de porosidad mediante técnica pulvimetalúrgica", Revista Matéria, v. 23, pp. 2018.

[11] ZAREIDOOST, A., YOUSEFPOUR, M., GHASEME, B., et al, "The relationship of surface roughness and cell response of chemical surface modification of titanium", J Mater Sci Mater Med, v. 23, pp. 1479$1488,2012$.

[12] GUADARRAMA, D., FOUILLEN, A., BADIA, A., et al, "A nanoporous titanium surface promotes the maturation of focal adhesions and formation of filopodia with distinctive nanoscale protrusions by osteogenic cells", Acta Biomaterialia, v. 60, pp. 339-349, 2017.

[13] ZHANG, J. Surface Property and Biocompatibility of Ti and Ti6Al4V for Dental Implants. in International Conference on Mechatronics, Electronic, Industrial and Control Engineering (MEIC). 2014. 
[14] GITTENS, R.A., SCHEIDELER, L., RUPPB, F., et al, "A review on the wettability of dental implant surfaces II: Biological and clinical aspects", Acta Biomaterialia, v. 10, pp. 2907-2918, 2014.

[15] TING, M., JEFFERIES, S.R., XIA, W., et al, "Classification and Effects of Implant Surface Modification on the Bone: Human Cell-Based In Vitro Studies", Journal of Oral Implantology, v. 43, pp. 5883, 2017.

[16] ELLINGSEN, J.E., MONJO, M., RAMIS, J.M., Development of a Novel Fluoride-Modified Implant Surface for Clinical Use, in Implant Surfaces and their Biological and Clinical Impact. 2015, Springer. p. 4564.

[17] WANG, G.-h., FU, H., ZHAO, Y.-z., et al, "Bone integration properties of antibacterial biomimetic porous titanium implants", Transactions of Nonferrous Metals Society of China, v. 27, pp. 2007-2014, 2017.

[18] JUNKER, R., DIMAKIS, A., THONEICK, M., et al, "Effects of implant surface coatings and composition on bone integration: a systematic review", Clinical oral implants research, v. 20, pp. 185-206, 2009.

[19] ZHANG, E.W., WANG, Y.B., SHUAI, K.G., et al, "In vitro and in vivo evaluation of SLA titanium surfaces with further alkali or hydrogen peroxide and heat treatment", Biomed.Mater., v. 6, pp. 1-7, 2011.

[20] LIN, X., ZHOU, L., LI, S., et al, "Behavior of acid etching on titanium: topography, hydrophility and hydrogen concentration", Biomed. Mater., v. 9, pp. 1-8, 2014.

[21] PELÁEZ-ABELLÁN, E., DUARTE, L.T., and BIAGGIO, S.R., "Modification of the Titanium Oxide Morphology and Composition by a Combined Chemical-electrochemical Treatment on cp Ti", Materials Research., v. 15, pp. 159-165, 2012.

[22] FERRARIS, S., BOBBIOB, A., MIOLA, M., et al, "Micro- and nano-textured, hydrophilic and bioactive titanium dental implants", Surface \& Coatings Technology, v. 1-9, 2015.

[23] HSU, H.-C., WU, S.-C., HSU, S.-K., et al, "Surface Modification of Commercially Pure Ti Treated with Aqueous $\mathrm{NaOH}$ Treatment and Ethyl Alcohol Aging", J. Med. Biol. Eng., v. 33, pp. 331-336, 2013.

[24] TEKER, D., MUHAFFEL, F., MENEKSE, M., et al, "Characteristics of multi-layer coating formed on commercially pure titanium for biomedical applications", Materials Science and Engineering C, v. 48, pp. 579-585, 2015.

[25] SUL, Y.T., KANG, B.S., JOHANSSON, C., et al, "The roles of surface chemistry and topography in the strength and rate of osseointegration of titanium implants in bone", J Biomed Mater Res v. 89A, pp. 942950, 2009.

[26] MILLERET, V., TUGULU, S., SCHLOTTIG, F., et al, "Alkali Treatment of Microrough Titanium Surfaces Affects Macrophage/Momocyte Adhesion, Platelet Activation and Architecture of Blood Clot Formation", European Cells and Materials, v. 21, pp. 430-444, 2011.

[27] RUPP, F., SCHEIDELER, L., OLSHANSKA, N., et al, "Enhancing surface free energy and hydrophilicity through chemical modification of microstructured titanium implant surfaces", J Biomed Mater Res, v. 76A, pp. 323-334, 2006.

[28] ELIAS, C.N., OSHIDA, Y., LIMA, J.H.C., et al, "Relationship between surface properties (roughness, wettability and morphology) of titanium and dental implant removal", Journal of the Mechanical Behavior of Biomedical Materials, v. 1, pp. 234-242, 2008.

[29] SCHWARZ, F., WIELAND, M., SCHWARTZ, Z., et al, "Review Potential of Chemically Modified Hydrophilic Surface Characteristics to Support Tissue Integration of Titanium Dental Implants", Journal of Biomedical Materials Research Part B: Appl Biomater, v. 88B, pp. 544-557, 2009.

[30] SORCAR, S., RAZZAQ, A., TIAN, H., et al, "Facile electrochemical synthesis of anatase nanoarchitectured titanium dioxide films with reversible superhydrophilic behavior", Journal of Industrial and Engineering Chemistry, v. 46, pp. 203-211, 2017.

[31] PAZ, A., REGUEIRA, Y.M., PAZOS, L. M., et al, "Obtención de recubrimientos de hidroxiapatita sobre titanio mediante el método biomimético", Revista de Metalurgia, v. 47, pp. 138-146, 2011.

[32] HSU, H.-C., WU, S.-C., HSU, S.-K., et al, "Surface Modification of Commercially Pure Ti Treated with Aqueous NaOH Treatment and Ethyl Alcohol Aging", Journal of Medical and Biological Engineering, v. 33, pp. 331-336, 2013.

[33] SHIBATA, Y. and TANIMOTO, Y., "A review of improved fixation methods for dental implants. Part I: Surface optimization for rapid osseointegration", Journal of prosthodontic research, v. 59, pp. 20-33, 2015. 
[34] DOHAN EHRENFEST, D.M., COELHO, P.G., KANG, B.-S., et al, "Classification of osseointegrated implant surfaces: materials, chemistry and topography", Trends in Biotechnology, v. 28, pp. 198-206, 2010.

[35] ROSALES-LEAL, J.I., RODRÍGUEZ-VALVERDE, M.A., MAZZAGLIA, G., et al, "Effect of roughness, wettability and morphology of engineered titanium surfaces on osteoblast-like cell adhesion", Colloids and Surfaces A: Physicochemical and Engineering Aspects, v. 365, pp. 222-229, 2010.

[36] WENNERBERG, A. and ALBREKTSSON, T., "Effects of titanium surface topography on bone integration: a systematic review", Clinical oral implants research, v. 20, pp. 172-184, 2009.

[37] WANG, X.-h., LI, J.-s., HU, R., et al, "Mechanical properties and pore structure deformation behaviour of biomedical porous titanium", Transactions of Nonferrous Metals Society of China, v. 25, pp. 1543-1550, 2015.

[38] RUPP, F., SCHEIDELER, L., REHBEIN, D., et al, "Roughness induced dynamic changes of wettability of acid etched titanium implant modification", Biomaterials, v. 25, pp. 1429-1438, 2004.

[39] WANG, G., MOYA, S., LU, Z., et al, "Enhancing orthopedic implant bioactivity: refining the nanotopography", Nanomedicine, v. 10, pp. 1327-1341, 2015.

[40] TAKEMOTO, S., YAMAMOTO, T., TSURU, K., et al, "Platelet adhesion on titanium oxide gels: effect of surface oxidation", Biomaterials, v. 25, pp. 3485-3492, 2004.

[41] OCAÑA, M., PECHARROMÁN, C., GRACÍA, F., et al, "Analysis of texture and microstructure of anatase thin films by Fourier transform infrared spectroscopy", Thin Solid Films, v. 515, pp. 1585-1591, 2006.

[42] FAURE, J., BALAMURUGAN, A., BENHAYOUNE, H., et al, "Morphological and chemical characterisation of biomimetic bone like apatite formation on alkali treated Ti6Al4V titanium alloy", Materials Science and Engineering: C, v. 29, pp. 1252-1257, 2009.

[43] LINDERBÄCK, P., HARMANKAYA, N., ASKENDAL, A., et al, "The effect of heat- or ultra violet ozone-treatment of titanium on complement deposition from human blood plasma", Biomaterials, v. 31, pp. 4795-4801, 2010.

[44] WANG, X.-X., HAYAKAWA, S., TSURU, K., et al, "A comparative study of in vitro apatite deposition on heat-, $\mathrm{H} 2 \mathrm{O} 2-$, and $\mathrm{NaOH}$-treated titanium surfaces", Journal of Biomedical Materials Research, v. 54, pp. 172-178, 2001

[45] PORKODI, K. and AROKIAMARY, S.D., "Synthesis and spectroscopic characterization of nanostructured anatase titania: A photocatalyst", Materials Characterization, v. 58, pp. 495-503, 2007.

[46] EKKERT, A.L., KYUNG W.K., GATTI, F., et al, "Efectos de tratamientos térmicos post-alcalinos sobre las propiedades superficiales de titanio para implantes dentales con diferentes recubrimientos.", Revista Matéria, v. 23, pp. 1-11, 2018.

[47] TRAID, H.D., VERA, M.L., ARES, A.E., et al, "Recubrimientos porosos de dióxido de titanio sintetizados por oxidación anódica. ", Revista Matéria, v. 23, pp. 1-7, 2018.

[48] LINDERBÄCK, P., HARMANKAYA, N., ASKENDAL, A., et al, "The effect of heat-or ultra violet ozone-treatment of titanium on complement deposition from human blood plasma", Biomaterials, v. 31, pp. 4795-4801, 2010.

[49] KARTHEGA, M., NAGARAJAN, S., RAJENDRAN, N., "In vitro studies of hydrogen peroxide treated titanium for biomedical applications", Electrochimica Acta, v. 55, pp. 2201-2209, 2010.

[50] TUGULU, S., LÖWE, K., SCHARNWEBER, D., et al, "Preparation of superhydrophilic microrough titanium implant surfaces by alkali treatment", Journal of Materials Science: Materials in Medicine, v. 21, pp. 2751-2763, 2010.

[51] BUSER, D., BROGGINI, N., WIELAND, M., et al, "Enhanced Bone Apposition to a Chemically Modified SLA Titanium Surface", J Dent Res, v. 83, pp. 529-533, 2004.

[52] RUPP, F., GITTENS, R.A., SCHEIDELER, L., et al, "A review on the wettability of dental implant surfaces I: Theoretical and experimental aspects", Acta Biomaterialia, v. 10, pp. 2894-2906, 2014.

[53] GITTENS, R.A., OLIVARES-NAVARRETE, R., CHENG, A., et al, "The roles of titanium surface micro/nanotopography and wettability on the differential response of human osteoblast lineage cells", Acta Biomaterialia, v. 9, pp. 6268-6277, 2013. 


\section{ORCID}

Alejandro López Cruz

https://orcid.org/0000-0002-2812-9960

Adrian Paz Ramos

https://orcid.org/0000-0003-0604-8999

Leonardo M. Pazos

https://orcid.org/0000-0002-4601-5561

María Belén Parodi

https://orcid.org/0000-0002-4878-9819

Gabriel Omar Ybarra

https://orcid.org/0000-0001-9931-0380

Jesús E. González Ruíz

https://orcid.org/0000-0002-3032-7819 